\title{
Postinfectious vasculitis
}

INSERM

\section{Source}

INSERM. (1999). Orphanet: an online rare disease and orphan drug data base.

Postinfectious vasculitis. ORPHA:48435

Vasculitis, characterized by inflammatory lesions in the wall of vessels, may be due to different viruses. 